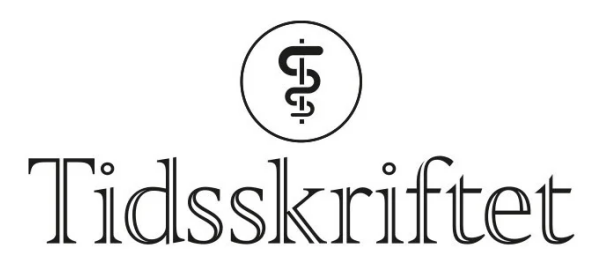

DEN NORSKE LEGEFORENING

\title{
Forskningens fartshumper
}

\author{
MINILEDER
}

ARE BREAN

Sjefredaktør

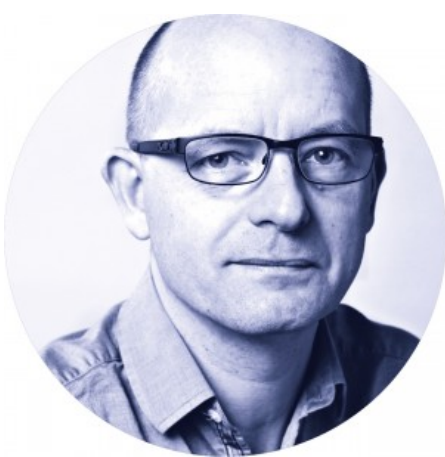

Verden har aldri tidligere sett en så rask og massiv forskningsinnsats knyttet til ett enkelt område som nå. Koronavirusforskningen sprenger kapasiteten til tradisjonell kvalitetssikring. I flere mindre fagfelt er det nå ikke nok eksperter til å fagfellevurdere alt så hurtig som det kreves - for «alt» er viktig og må raskt ut.

En av konsekvensene er en enorm økning i antallet manuskripter publisert på såkalte preprint-servere, som tilbyr publisering uten fartsbegrensning. En av de største, medRxiv, rapporterer om over hundre ganger så mange nedlastinger som før pandemien. Men preprint-manuskripter er bare vurdert av forskerne selv, og har ikke passert forskningens fartshumper - den trauste og møysommelige vitenskapelige vurderingen som fagfeller og tidsskriftredaksjoner står for. Når generelle aviser og medier uten trening i å kritisk vurdere vitenskap skal fortelle sine lesere om det siste nye, går det poenget lett hus forbi. Det har i mange tilfeller gitt medvind til både "fake news» og konspirasjonsteorier. Nå har flere preprint-servere selv tatt grep og stilt krav om ekstern vurdering av manuskriptene før de publiseres. Dermed nærmer de seg mer tradisjonell vitenskapelig publisering. Fartshumper er kjedelige for den som vil fort frem. Men de gjør verden tryggere for oss alle.

Publisert: 4. mai 2020. Tidsskr Nor Legeforen. DOI: 10.4045/tidsskr.20.07.01

(C) Tidsskrift for Den norske legeforening 2023. Lastet ned fra tidsskriftet.no 26. april 2023. 